\title{
Perceiving Cultural Heritage
}

\author{
MASSIMO BERGAMASCO, Scuola Superiore Sant'Anna, Pisa, Italy \\ PERLA GIANNI FALVO, Art Perception, Florence, Italy \\ GIOVANNI VALERI MANERA, Art Perception, Florence, Italy
}

Over the years, we have undertaken research projects in the field of cultural heritage perception, trying to analyze the response of the human cognitive system when immersed in Virtual Reality, Augmented Reality or other multimedia supports. Our goal has been to study how to improve design exhibition, utilizing these technologies in museums and cultural heritage sites and to study alternative ways to promote human development through a deeper contact with art.

\section{Key words:}

Aesthetic perception, neurosciences, transmission of cultural heritage.

SDH Reference:

Massimo Bergamasco, Perla Gianni Falvo, Giovanni Valeri Manera. 2018. Perceiving Cultural

Heritage. SDH, 2, 1, II-V.

DOI: $10.14434 /$ sdh.v2i1.27979

Perceiving cultural heritage means coming into contact with a special condensate that represents the human being himself, his relationship with his own identity and the outside world. "Man, in fact, is the only animal that leaves testimonies behind him, since he is the only one whose artefacts bring to mind an idea different from that of their material existence" [Panofsky 1955]. The traces of this human capacity, which shows the need to outsource one's identity and to extend one's presence in space and time, are further away from us than we imagine: between 430,000 and 540,000 years ago, when a Homo Erectus at Trinil in Java used shells for tool production and engraving [Joordens et al. 2014]. "The term humanitas has had two very distinct meanings. The first results from the comparison between man and what is less than man; the second from the comparison with man and what is more than man. In the first case, with humanitas we mean a quality, in the second a limit." Thus, wrote Erwin Panofsky, expressing thereby the basis of Humanism and the Renaissance. The Renaissance admirably condenses its vision of man in the world with the invention of perspective representation that canonizes the point of view of a human observer. The image of the human being and its centrality, promulgated through the various multimedia means of communication of the time - painting, sculpture, architecture, the scenography of great events and sacred representations designed by artists of the caliber of Michelangelo and Brunelleschi [Olschki 2001], as well as philosophy and the nascent scientific revolution- led to the cultural awakening of the Renaissance, which is at the root of contemporary Western culture. Ergonomics derives from the same impulse

\footnotetext{
Authors' addresses: Massimo Bergamasco, Perceptual Robotics Laboratory (PERCRO), Sant'Anna School of Advanced Studies, Via G. Moruzzi 1, 56124, Pisa, Italy; email: massimo.bergamasco@santannapisa.it; Perla Gianni Falvo and Giovanni Valeri Manera, Art Perception International, Via Orcagna, 53, 50121 Florence, Italy; emails: perla@artperception.org; giovanni@artperception.org.

(C) [2018] by the authors; licensee Studies in Digital Heritage, IU, Bloomington (IN), USA. This article is an open access article distributed under the terms and conditions of the Creative Commons Attribution License (CC BY-NC).
} 
that gave birth to perspective: it takes its point of departure from the assumption that things must be dimensioned in conformity with the characteristics of the human body, and that they are at the service of the body's extension. The topics related to the Users eXperience (UX) further deepen and specialize this vision with the support of cognitive neuroscience that "allows us to formulate a new model of perception in which action, perception and cognition are closely integrated, and in which multimodal integration, modelled on the bodily experience we make of the world, shapes how our brain through the body maps our being in the world" [Gallese and Guerra 2015].

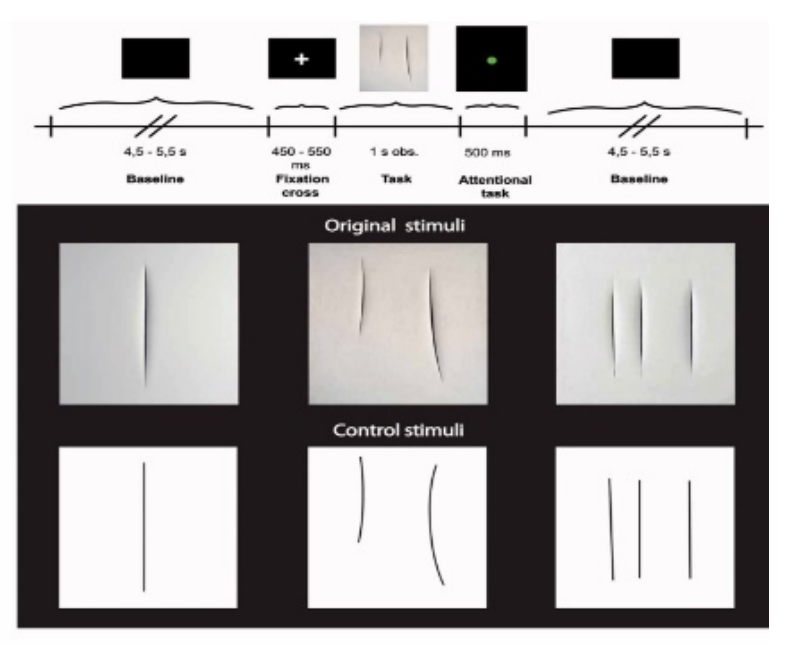

a)

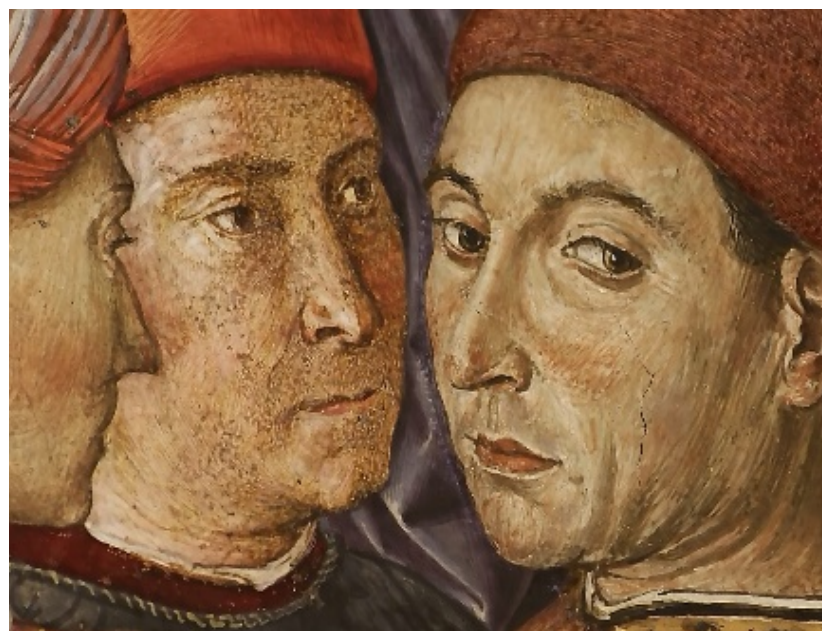

b)

Figure 1. Art Perception: a) Lucio Fontana's cuts on canvas. In studying the neurophysiological effects these works of art it was experimentally verified the activation of the motor areas assigned to the cutting activity; $b$ ) Benozzo Gozzoli chapel, Palazzo Medici Riccardi, Florence (Italy). Detail of the fresco.

Art condenses human activity in a coherent and meaningful form, surprising us, adding elements to our sense of humanity, in both the way we perceive ourselves internally and relative to the external world [Gardner 1993]. Art represents man and his actions in a living form, able to relate to other human beings overcoming space-time barriers [Cassirer 1923; Cassirer 1925; Cassirer 1929], suggesting resonances with individual experience and reflections on human existence. It offers the aesthetic expression of the meaning of life, the bearer of emotions and messages that take the form of a language.

"Every man is capable of feeling all human feelings, while not every man knows how to express them all," wrote Leo Tolstoy in "What is art?" This insight foreshadowed what cognitive sciences show us more clearly today [Tolstoy 1904].

The recent discovery of mirror neurons sheds new light on the phenomenon of the relation between the subject and the object [Gallese et al. 2002; Freedberg and Gallese, 2007]. Mirror neurons confirm in an experimental way the presence of automatic cognitive abilities that all human beings share. Other studies have also shown that cultural transmission concerns a learning phenomenon that includes sensorimotor channels (which are prelinguistic) [Gallese 2009], symbolic and conceptual 
channels [Antinucci 2011]. This scientific research should guide museum exhibition designers to set perceptual events in space bearing in mind what factors "are relevant to someone going to an art exhibit ... making people more focused, better able to concentrate and ignore distractions, which you must do if you are going to stand in front of a painting and have a rapport with what that painting is telling you about the world" [Gianni Falvo et al. 2018].

The identity formation of a person, community, or nation has a foundation in its cultural production and is strengthened by the relationship with the contents of the cultural heritage productions. In this context, Carlo Ludovico Ragghianti wrote: "Therefore the results of a good and adequate reading of poetry, or painting, far from transporting or confining us in a gratuitous aestheticism, can therefore be, as far as education is concerned, and therefore the individual liberation, much more fruitful and profound than a book, for example, of sociology!" In his latest essay he added that "It is necessary to widen the space for art. It is necessary to increase the circulation of the values and problems of art, which are essential factors of civilization. It is necessary to make possible a broad and continuous participation of the public, of society" [Ragghianti 1965]. It follows that the way in which the experience of cultural heritage is designed is crucial for the creation of a context in which everyone can elaborate their meaning, connect it to their personal history and establish a relationship with the work of art.

To study the exciting phenomenon of aesthetic perception in its complexity requires the simultaneous input of the sciences of nature and of culture. Once again, we would like to thank the publishers and all those who in various ways have contributed to this Special Issue dedicated to aesthetic perception and to the emergence of reference elements for museum design. We hope that the vision offered by these interventions will promote the progressive definition of a shared research protocol on the effects of aesthetic perception.

\section{ACKNOWLEDGMENT}

We thank the editors-in-chief for giving us the opportunity to publish this Special Issue as well as all the authors who agreed to contribute to it.

\section{REFERENCES}

Antinucci F. 2011. Parola e immagine, storia di due tecnologie, Editori Laterza, Bari, Italy. Arnheim, Rudolf. 2004. Art and Visual Perception, a Psychology of the Creative Eye. University of California Press, Oakland (CA), USA.

Cassirer, Ernst. 1923. Philosophie der symbolischen Formen. Erster Teil: Die Sprache. Berlin: Bruno Cassirer. Translated as The Philosophy of Symbolic Forms. Volume One: Language. New Haven: Yale University Press, 1955.

Cassirer, Ernst. 1925. Philosophie der symbolischen Formen. Zweiter Teil: Das mythische Denken. Berlin: Bruno Cassirer. Translated as The Philosophy of Symbolic Forms. Volume Two: Mythical Thought. New Haven: Yale University Press, 1955.

Cassirer, Ernst. 1929. Philosophie der symbolischen Formen. Dritter Teil: Phänomenologie der Erkenntnis. Berlin: Bruno Cassirer. Translated as The Philosophy of Symbolic Forms. Volume 
Three: The Phenomenology of Knowledge. New Haven: Yale University Press, 1957.

Freedberg D. and Gallese V. 2007. Motion, emotion and empathy in esthetic experience. Trends in Cognitive Sciences, 11, 197-203.

Gallese V. 2009. Neuroscienze e fenomenologia in Enciclopedia Treccani terzo millennio, Institute of the Italian Encyclopedia, Rome, Italy.

Gallese V. and Guerra M. 2015. Lo schermo empatico. Cinema e neuroscienze. p.218. Raffaello Cortina. Milano, Italy.

Gallese, V., Fadiga, L., Fogassi, L., and Rizzolatti, G. 2002. Action representation and the inferior parietal lobule. In Prinz, W., and Hommel, B. (Eds.) Common Mechanisms in Perception and Action: Attention and Performance, Vol. XIX. Oxford: Oxford University Press, 247-266.

Garbero Zorzi E. and Sperenzi M. 2001. Teatro e spettacolo nella Firenze dei Medici. Olschki, Florence, Italy.

Gianni Falvo P, Valeri Manera G and Zoss J. 2018. Conversation with Daniel Goleman about the relationship between the person viewing art and the art itself. Studies in Digital Heritage, 2(1), XXV. https://doi.org/10.14434/sdh.v2i1.26872

Howard, Gardner. 1993. Multiple Intelligences: The Theory in Practice, Basic Books, ISBN 9780465018222.

Joordens, J.C.A., d'Errico, F., Wesselingh, F.P., Munro, S., de Vos, J., Wallinga, J., Ankjærgaard, C., Reimann, T., Wijbrans, J.R., Kuiper, K.F., Mücher, H.J., Coqueugniot, H., Prié, V., Joosten, I., van Os, B., Schulp, A.S., Panuel, M., van der Haas, V., Lustenhouwer, W., Reijmer, J.J.G., Roebroeks. W. 2014. Homo erectus at Trinil on Java used shells for tool production and engraving. Nature. 518, 228-231.

Panofsky E. 1955. Meaning in the Visual Arts. The University of Chicago Press, Chicago (IL), USA. Ragghianti C.L. 1961. Divulgazione, Sele Arte, 54, p. 45.

Tolstoj, Lev. 1904. Che cosa è l'arte? Traslation from Russian to Italian authorized by the author. Fratelli Treves Editori, Milan, Italy.

Accepted: September 2018.

Studies in Digital Heritage, Vol. 2, No. 1, Publication date: September 2018 